\title{
INVESTIGATIONS IN OZONE APPLICATION FOR ACTIVE VENTILATION OF GRAIN
}

\author{
Adolfs Rucins $^{1}$, Evita Straumite ${ }^{1}$, Dainis Viesturs ${ }^{1}$, Alberts Kristins ${ }^{2}$ \\ ${ }^{1}$ Latvia University of Life Sciences and Technologies, Latvia; \\ ${ }^{2}$ Institute of Solid State Physics, University of Latvia, Latvia \\ adolfs.rucins@1lu.lv, viesturs_uzc@apollo.lv,
}

\begin{abstract}
The article presents an analysis of previous research on the use of ozone to intensify the active ventilation of grain. It shows the results of two year experiments revealing possibilities of using ozone in active ventilation of grain in $20 \mathrm{~m}^{3}$ tanks under farm conditions. The essence of the experiments: two equal tanks are loaded with the same amount of grain of the same humidity and are ventilated with the same intensity of air flow by adding generator-produced ozone with a concentration of $28 \mathrm{mg} \cdot \mathrm{m}^{-3}$ to the ventilated air of one tank. The sensor system, installed in the tanks, performs real-time monitoring and records the parameters of the drying process, which are also periodically checked with hand tools. A decrease in the grain moisture in the ozone tank was established during the experiments in contrast to the tank without ozone additive in the ventilation air, especially in the lower layers of the tank. It was found that the ozone additive of the concentration mentioned can be rationally applied in the treatment of $1.5-2.0 \mathrm{~m}$ high grain layer at the ventilation parameters indicated in the article.
\end{abstract}

Keywords: grain drying, ozone treatment, sensor system.

\section{Introduction}

Technologies that reduce environmental impact will become increasingly important in agriculture. One of such technologies could be application of ozone in grain growing and processing. There are investigations carried out on the impact of ozone upon grain at various stages the technology - the seed treatment, the grain aeration and storage; yet most studies have been performed under the laboratory conditions, with a small amount of grain, under different weather conditions. Also concerning application of ozone in the active ventilation of grain, most investigations have been made under laboratory conditions - by treating a small amount of grain with ozone in the equipment specially designed for this purpose. Most often the amount of grain in such experiments does not exceed a few tens of kilograms, the height of the grain layer - one metre [1-3]. The initial moisture content of the treated grain varies from $28 \%$ [4] to $14 \%$ [6]. The concentration of the applied ozone depends mainly on the purpose of treatment - the most commonly used ozone concentration for ventilation intensification is $8-10 \mathrm{mg} \cdot \mathrm{m}^{-3}[4 ; 5 ; 7]$, while for the mycotoxin extermination purposes a concentration of up to $100 \mathrm{mg} \cdot \mathrm{m}^{-3}$ is recommended [8;9]. Several authors $[1 ; 4 ; 5]$ indicate an air flow rate of $0.2-$ $0.4 \mathrm{~m} \cdot \mathrm{s}^{-1}$.

There are also studies on the use of an ozone additive to the ventilation air in large volume tanks. The authors of [10] describe experiments with a $2.7 \mathrm{~m}$ high grain layer and significant ozone concentration in the ventilation air $-21.0-42.0 \mathrm{mg} \cdot \mathrm{m}^{-3}$. There are experiments performed [5] in two 30 $\mathrm{m}^{3}$ tanks, the ventilation air in both tanks being heated by $5-60{ }^{\circ} \mathrm{C}$, adding ozone of a low concentration to the air in one tank. Also in [11] air heated to $50 \mathrm{C}$ and ozone concentration of $3-5 \mathrm{mg} \cdot \mathrm{m}^{-3}$ are used for ventilation. The authors of the performed experiments believe that such ventilation conditions shorten the drying time by about $20 \%$. On the other hand, the conclusions of experiments, performed both under laboratory conditions and in large-volume tanks, indicate that the drying speed increases up to two times, yet the process parameters are not indicated [7]. In 2019 the experiments with active ventilation of grain in two $20 \mathrm{~m}^{3}$ tanks, adding ozone to the air in one tank with a concentration of $28 \mathrm{mg} \cdot \mathrm{m}^{-3}$, with the initial height of the grain layer of $5.1 \mathrm{~m}$ were performed by [12]. The authors conclude that there is a slight decrease in the grain moisture in the ozone tank in contrast to the tank without ozone additive to ventilation air; yet the advantages of the method have not been convincingly proved. Therefore, experiments were continued in 2020 during the next grain harvesting season, performing ventilation in both tanks for a 3.0-3.5 m high layer of grain.

All the authors of these publications believe that application of ozone give a positive effect in shortening the drying time, the numerical values of the process shortening are mentioned within the range from 10 to $100 \%$, most often $10-25 \%$. Most often the ozone concentration is $5-30 \mathrm{mg} \cdot \mathrm{m}^{-3}$, the initial humidity of the ventilated grain is $28-18 \%$. In most cases the air flow rate is $0.1-0.4 \mathrm{~m} \cdot \mathrm{s}^{-1}$, the duration of experiments was from a few hours in the laboratory to 12 days in the large-volume tanks. 
Obviously, the authors of these investigations have different views on the ozone application modes and results of grain drying by active aeration in high-volume tanks, which have also an objective reason because the experiments were performed under different conditions.

The aim of the research is to continue the experiments started in 2019 [12] to find out the possibilities and efficiency of the ozone application under the farm conditions, ventilating during the grain harvesting a 3.0-3.5 m high grain layer in two identical $20 \mathrm{~m}^{3}$ tanks, by adding ozone to one tank, the other without the ozone addition.

\section{Materials and methods}

The experiments started in 2019 were continued in 2020 at a grain pre-processing centre of a farm by ventilating wet grains in two equal tanks with a maximum capacity of 20 tons - in one with unheated outdoor air, in the other with ozone added to the unheated outdoor air (Fig. 1). The methodology of the experiments is laid out in publication [12]; there is a significant difference in the initial height of the grain layer to be treated - in 2019 it was $5.1 \mathrm{~m}$ but in 2020 it was $3.2 \mathrm{~m}$ (shaded in the figure). At the grain layer height of $5.1 \mathrm{~m}$ it was not possible to achieve the required air flow rate in the grain; therefore, in the upper layers drying of the grain was insufficient, while in the lower layers the grain was overdried to $11 \%$ moisture. The ozone concentration was optimal only in the first and the second layer - around $10 \mathrm{ppm}$; in the third layer - about half of what was required; in the above layers the ozone effect was minimal. Therefore, in 2020 the experiments were continued with an initial layer height of $3.2 \mathrm{~m}$.

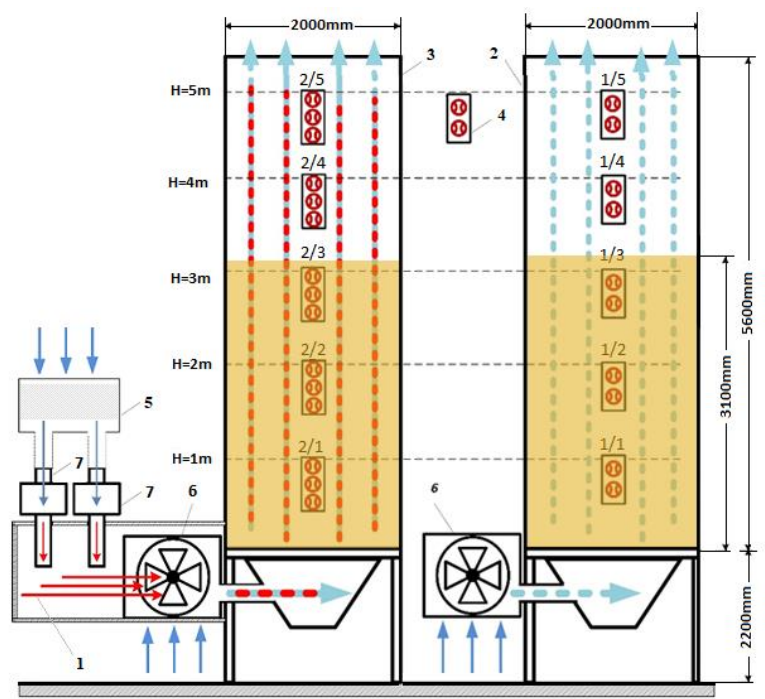

Fig.1. Scheme of the ventilation tank, the tank filling: to the height (coloured) of to $5.1 \mathrm{~m}$ in 2019 , to $3.2 \mathrm{~m}$ in $2020 ; 1 / 1-1 / 5 ; 2 / 1-2 / 5$ - sensors; 1 - ozone; 2 - tank without ozone; 3 - tank with ozone; 4 - outside sensors; 5 - air dust filter; 6 - fans; 7 - ozone generators

The tanks for performing experiments are equipped with fans, their engine power being $4.0 \mathrm{~kW}$, the impeller speed $2800 \mathrm{~min}^{-1}$, the efficiency $7000 \mathrm{~m}^{3} \cdot \mathrm{h}^{-1}$. Two ozone generators are arranged in front of the fan of one tank, the installed power of each being $1 \mathrm{~kW}$, the output $100 \mathrm{~g} \cdot \mathrm{h}^{-1} \mathrm{O}_{3}$; so the total output $200 \mathrm{~g} \cdot \mathrm{h}^{-1} \mathrm{O}_{3}$. In the centre of each tank there is a suspension for fixing the sensor system, installing boxes with sensors per every metre; the structure and operating principles of the sensor system are described in publication [13], the methodology of using the sensor system - in publication [12]. The sensor system is designed to record air humidity in the interspace, temperature and ozone concentration per meter; in 2019 in five layers, in 2020 in three layers; and to transmit the recorded data to the computer where real-time online or remote monitoring can be performed. The following parameters were determined during the experiments by stationary meters, a sensor system or by hand tools.

- Energy consumption by the fan connected to each tank, kWh.

- Energy consumption by ozone generator, $\mathrm{kWh}$.

- The air humidity in both tanks in the grain interspace in five layers (height $5.1 \mathrm{~m}$ ) in 2019 ; in three layers (height $3.2 \mathrm{~m}$ in 2020), \%. 
- The grain temperature in both tanks in five layers $(5.1 \mathrm{~m})$ in 2019 ; in three layers $(3.2 \mathrm{~m})$ in $2020,0{ }^{\circ} \mathrm{C}$.

- The ozone concentration in the tank with the ozone supply in five layers (5.1 $\mathrm{m}$ ) in 2019 ; in three layers $(3.2 \mathrm{~m})$ in 2020 , ppm.

- The ambient air humidity and temperature, $\%, 0^{\circ} \mathrm{C}$.

- The grain moisture in containers per layers periodically measured during drying by a hand tool (Wile 66 (FarmComp Oy, Finland). Humidity range 8-35\% with grain, 6-25\% with the oil plants. Measuring accuracy $\pm 0.5 \%$ for the whole grain. Better than $\pm 0.5 \%$ for the ground grain. Storage temperature $\left.-15^{\circ} \mathrm{C}+50^{\circ} \mathrm{C}\right), \%$.

- The ozone concentration at the inlet of the ozone tank, above the top layer of the grain and at a depth of $2 \mathrm{~m}$ from above, during periodic drying with a hand tool (QL-800-O, Manufacturer QLOZONE, China), with a monitoring range from 0 to $100 \mathrm{ppm}$, with a resolution of $0.01 \mathrm{ppm}$. The ozone conversion, measured by volume in the air, is $1 \mathrm{ppm}$ of ozone $=2.14 \mathrm{mg} \cdot \mathrm{m}^{-3} \mathrm{O}_{3}$ ), ppm.

- The air discharge rate above the top layer of the grain in both tanks periodically during drying with a hand tool, $\mathrm{m} \cdot \mathrm{s}^{-1}$.

Mathematical statistical methods were used to process the results.

\section{Results and discussion}

In 2019 experiments were performed with approximately $5.1 \mathrm{~m}$ high grain layer, the grain mass in each tank being approximate $17.4 \mathrm{t}$, the initial grain humidity $23 \%$, the total ventilation duration 28 days. During this period the fans were operated for 185 hours, an average of 6.60 hours per day. The parameters, registered by the sensor system, could be monitored both at the moment, and, for the previous days, on the computer of the farm, and from distance; the total number of the operating sensors was 27. During the first week an intense decrease in moisture was observed in the lower layer, then also in the second layer from the bottom. The temperature in the layers varied in the range of $15-26^{\circ} \mathrm{C}$, it was higher in the upper layers. The ozone concentration was the highest in the lower layer, decreasing in the second and the third layers, and was negligible in the fourth and fifth layers. At the end of the second week the grain moisture at the top of the tanks and at a depth of $1.5 \mathrm{~m}$ from the top decreased little - to $17.5 \%$ in the ozone tank, and $18.5 \%$ in the ozone-free tank; the grain drying had started in the third layer from the bottom. At the same time the grain at the bottom of the tank were overdried - the moisture being $11 \%$. The reason for the high moisture of the grain in the upper layers of the tanks is obviously the insufficient specific air consumption per $1 \mathrm{~m}^{3}$ of the grain per hour. In our case this indicator is $350 \mathrm{~m}^{3} \cdot \mathrm{h}^{-1}$, the optimum would be $500-550 \mathrm{~m}^{3} \cdot \mathrm{h}^{-1}$ [14]. In order to intensify the process, it was decided to reduce the height of the grain layer in the tanks by about half, releasing part of the driest grain from the bottom of the tanks and delivering it for sale with an average humidity of $17.5 \%$. Continuing aeration of the remaining grain-about $50 \%$ of the volume of the tank - on the following days the grain moisture in the lower layers of the tanks decreased comparatively rapidly, at the top of the tanks it decreased less. After about a week the grain moisture at the bottom of the tanks was already 11$12 \%$, therefore its aeration was stopped, and the grain was delivered for sale with an average moisture content of $15.2 \%$.

The air flow rate above the grain layer and the ozone concentration at the fan inlet and at the top of the tank were periodically checked by hand tools. The air flow above the grain layer, depending on the position of the measuring instrument in relation to the centre of the tank, was $0.05-0.06 \mathrm{~m} \cdot \mathrm{s}^{-1}$, which is at least twice less than the minimum required for intensive ventilation of the grain [14]. The ozone concentration in the fan inlet pipe was $15-18 \mathrm{ppm}$, which even exceeds the planned concentration of $13 \mathrm{ppm}$ or $28 \mathrm{mg} \cdot \mathrm{m}^{-3} \mathrm{O}_{3}$. The ozone concentration at the top of the tank was around $0.1 \mathrm{ppm}$, which means that virtually all the ozone has been absorbed - as confirmed by the sensor system - at the fourth and fifth levels the ozone concentration is negligible [12].

When evaluating the results of the experiments of the year 2019, it was found that the use of ozone in a short ventilation cycle (2-3 days) allows to reduce the moisture in the grain layer, up to $3 \mathrm{~m}$ thick, by about $1 \%$, in contrast to the outdoor ozone-free ventilation. It was also found that, using the fans installed on the farm, the experiments should be continued in 2020 with a $3 \mathrm{~m}$ high grain layer, because ventilation of the upper layers is not efficient enough. It has also been established that the sensor system, 
developed and installed in the tanks, worked in accordance with the requirements, and it can be used for monitoring the drying process and the data collection also in 2020.

Taking into account the results of 2019 [12], in 2020 the experiments were performed with about $3.2 \mathrm{~m}$ high grain layer; the approximate grain mass in each tank was $10.8 \mathrm{t}$, the initial grain humidity $23.5 \%$, the total ventilation duration 22 days; during this period the fans were operated for 136 hours or an average of 6.18 hours per day; ventilation started on 22.07.2020. The ventilation process was monitored by a sensor system; additional process parameters were periodically determined by hand tools, using the methodology developed for the 2019 experiments [12].

Variations in the grain moisture during drying in the tank with ozone (Tank with Ozone-OT) and in the ozone-free tank (Reference tank - RT), periodically determining the humidity by a hand tool in triplicate, are shown in Table 1. The samples of grain for the moisture determination in several layers of the tanks ( $1 \mathrm{~m}$ from the top, $2 \mathrm{~m}$ from the top, $3 \mathrm{~m}$ from the top) were taken with a probe provided for this purpose.

Table 1

Variations in the grain moisture during drying in the ventilation tanks by layers

\begin{tabular}{|c|c|c|c|c|c|c|c|c|c|c|}
\hline \multirow{2}{*}{$\begin{array}{c}\text { Date } \\
\text { Moistue, \% }\end{array}$} & \multicolumn{2}{|c|}{ 23.07.2020. } & \multicolumn{2}{|c|}{ 28.07.2020. } & \multicolumn{2}{|c|}{ 3.08.2020. } & \multicolumn{2}{|c|}{ 6.08.2020. } & \multicolumn{2}{|c|}{ 12.08.2020. } \\
\hline & Ozone & $\begin{array}{l}\text { Ozone- } \\
\text { free }\end{array}$ & Ozone & $\begin{array}{l}\text { Ozone } \\
\text {-free }\end{array}$ & Ozone & $\begin{array}{l}\text { Ozone- } \\
\text { free }\end{array}$ & Ozone & $\begin{array}{l}\text { Ozone- } \\
\text { free }\end{array}$ & Ozone & $\begin{array}{l}\text { Ozone- } \\
\text { free }\end{array}$ \\
\hline On top of the tank & 22.0 & 22.0 & 22.0 & 22.0 & 19.0 & 19.0 & 18.0 & 18.0 & 18.0 & 18.0 \\
\hline $1 \mathrm{~m}$ from the top & 22.0 & 22.0 & 22.0 & 22.0 & 19.0 & 19.0 & 17.5 & 18.0 & 17.5 & 18.0 \\
\hline $2 \mathrm{~m}$ from the top & no data & no data & 22.0 & 22.0 & 18.0 & 19.0 & 17.5 & 18.0 & 16.5 & 17.5 \\
\hline $3 \mathrm{~m}$ from the top & no data & no data & 15.0 & 18.0 & 12.0 & 14.0 & 10.0 & 11.0 & 9.5 & 10.0 \\
\hline $\begin{array}{l}\text { At the bottom of } \\
\text { the tank }\end{array}$ & 13.0 & 14.0 & 11.0 & 12.0 & 10.0 & 10.0 & 9.0 & 9.0 & 8.0 & 9.0 \\
\hline
\end{tabular}

As evident from the table, the grain moisture has changed differently in different layers of the tank - at the bottom of the tank, already after one-day ventilation, the grain has reached the condition moisture (14\%); besides, in the tank with the ozone supply the humidity is by $1 \%$ lower. During the subsequent ventilation the grain at the bottom of the tanks were overdried $(11 \%)$ - similar to what was found in 2019. In the next layer $-3 \mathrm{~m}$ from the top - the ozone effect is visible five days after the start of ventilation - 28.07.2020 - when the grain moisture in the ozone tank is $3 \%$ lower than in the tank without the ozone supply. The ozonation effect of grain in this layer is also visible in the subsequent course of drying, but as the grain becomes drier (11\%), it gradually decreases. On the 12.08.2020 the moisture content of the grain in the ozone tank is only $0.5 \%$ lower than in the tank without the ozone supply, and the grain is also overdried in this layer (11\%). For technical reasons on the 23.07.2020 it was not possible to determine the grain moisture. In its turn, in the layer $2 \mathrm{~m}$ from the top, the effect of ozone can be detected 12 days after the start of ventilation - on the 03.08 .2020 - when the moisture content of the grain in the ozone-containing tank is $1 \%$ lower; a small difference in moisture remains until the end of the drying period. In the layer $1 \mathrm{~m}$ from the top, the ozonation effect appears on the fifteenth day after the start of ventilation and is only $0.5 \%$. In the upper layer, on the other hand, the effect of ozone cannot be detected - in both tanks the grain moisture is $18 \%$, and during 22 days it has decreased by $5.5 \%$. The experiments confirmed the statements in the literature [1], [2] that the impact of ozone is effective at the beginning of the ventilation period - up to a few days when ozone intensively absorbs the grain moisture. This is also evident in the table - in the rows " $3 \mathrm{~m}$ from above" and "at the bottom of the tank".

Periodically, by a hand tool in triplicate, the air flow rate, as well as the ozone concentration at various locations were determined in the tanks above the top layer of grain. The air flow rate was measured by placing the meter at five symmetrical points above the grain layer in triplicate and then calculating the average value. In the measurements of the year 2020 the air flow velocity was found to be $0.08-0.09 \mathrm{~m} \cdot \mathrm{s}^{-1}$, which is $1.5-1.6$ times more, compared to the measurements of the year $2019(0.05-$ $0.06 \mathrm{~m} \cdot \mathrm{s}^{-1}$ ) above the $5.1 \mathrm{~m}$ high layer of grain. However, the flow rate fixed in the year 2020 also lags behind the optimum for intensive grain ventilation $-0.1-0.2 \mathrm{~m} \cdot \mathrm{s}^{-1}[14]$. 
The ozone concentration was periodically measured by a hand tool in three replicates at the fan inlet, above the grain layer and $2 \mathrm{~m}$ from above. The concentration in the inlet was similar to that in the year 2019 - 15-17 ppm, which exceeds the planned concentration $13 \mathrm{ppm}$ of air. The concentration of ozone above the upper layer at the beginning of ventilation is not detectable, after about two hours it was within the range of 0.1-0.3 ppm, a higher value was found in the drier grain. At $2 \mathrm{~m}$ from the top of the layer the ozone concentration was approximately $4 \mathrm{ppm}$. Measurements of the sensor system show a similar concentration. On the whole, the ozone concentration complies with the planned one.

To illustrate the operation of the sensor system, Figure 2 shows the fixed results of the sensor system in the ozone tank during one day. Ventilation and the ozone delivery started on the 23.07.2020 at 17.45. As shown in Figure 2a, moisture in the lower layer (sensor 2/1;1 m) in the grain interspace gradually decreases. As soon as the equipment is switched off at 21.25 , the humidity is rising rapidly again. In the following layers the changes are much smaller (sensor $2 / 2 ; 2 \mathrm{~m}$, sensor $2 / 3 ; 3 \mathrm{~m}$ ). The temperature changes during ventilation can be observed within the range of $3-4^{\circ} \mathrm{C}$ (Fig. 2b), besides, in the lower layer (sensor $2 / 1 ; 1 \mathrm{~m}$ ) it increases; in the following layers it decreases slightly during the whole ventilation time. Such a nature of changes in the temperature curves was also observed in the experiments of the year 2019. As shown in Figure 2c, the ozone concentration increases rapidly in the lower layer (sensor $2 / 1 ; 1 \mathrm{~m}$ ), in the second and third layers from the bottom (sensor $2 / 2 ; 2 \mathrm{~m}$, sensor $2 / 3 ; 3 \mathrm{~m})$ the changes are similar, but flatter.
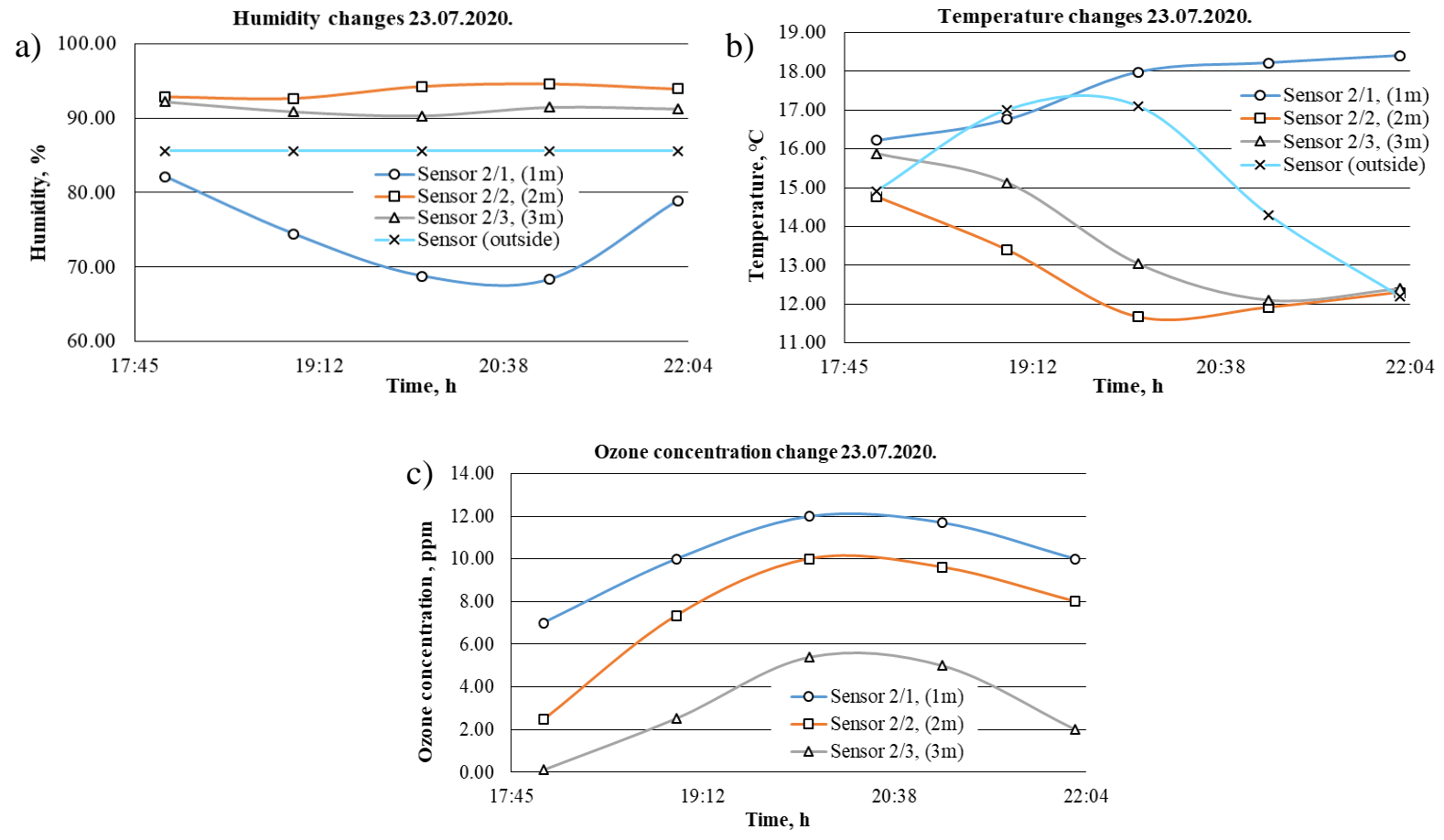

Fig.2. Results fixed by the sensor system in the ozone tank during one day:

$\mathrm{a}$ - humidity changes; $\mathrm{b}$ - temperature changes; $\mathrm{c}$ - ozone concentration changes

If the results of the experiments conducted in 2020 are compared with the results of the year 2019, it can be concluded that the results of the year 2020 prove more convincingly the purposefulness of the ozone application. As it is obvious from the table, already after six days of ventilation in the ozone tank, $1 \mathrm{~m}$ from the bottom of the tank, the grain moisture is $3 \%$ lower than in the tank without the ozone supply, which is essential. Continuing the aeration and reducing humidity below the condition humidity of 14\% (the grain overdrying), this difference decreases, because ozone has no effect upon the dry grain. Also in the layer $2 \mathrm{~m}$ from the bottom of the tank the difference in the grain moisture in both tanks is $1 \%$, although only after 12 days of ventilation. The obtained results are similar to the results of other studies $[6 ; 15]$ - the higher the grain moisture content, the slower the ozone penetration through the grain layer; respectively, the higher the ozone absorption.

The lowest ozonation efficiency appears $3 \mathrm{~m}$ from the bottom of the tank (i.e., close to the top of the layer) $-0.5 \%$ grain moisture difference, and only after 15 days of ventilation, the grain moisture in 
the top grain layer is the same in both tanks. As already mentioned, the ozone concentration above the grain layer is negligible; besides the moisture removed from the lower layers is partially condensed in the upper layer.

\section{Conclusions}

1. Active attachment of ozone in wet grain (18-23\%) takes place at the beginning of ventilation and mainly in the lower layers of the grain. As the grain moisture decreases and the layer thickness increases, the effect of ozone application also decreases.

2. After six days of ventilation in a one metre thick grain layer of ozone with a concentration of 0.028 $\mathrm{g} \mathrm{m}^{3}$, the moisture content of the grain is by $3 \%$ lower than the moisture content of the grain without an ozone additive to the ventilation air. The condition moisture in a one metre thick layer of ozone is reached 3 days faster than without ozone.

3. In a two-meter-thick layer, the grain moisture decreases considerably more slowly and the effect of the ozone application is less. After 12 days of ventilation, it is $18 \%$ for the grain with ozone added to the ventilation air and $19 \%$ without ozone.

4. In a three-metre-thick layer, during 22 days (136 hours) of ventilation, the humidity decreased only by 4.5 and $4.0 \%$, respectively, the result of ozone exposure is minimal.

5. To sum up what was mentioned above, one can conclude that it is expedient to apply the ozone in active ventilation with a concentration of $28 \mathrm{mg} \cdot \mathrm{m}^{-3}$ at the ventilation parameters, mentioned in the second part of the article, with the initial humidity of $22-23 \%$ and the layer thickness up to $1.5 \mathrm{~m}$, maximum $2 \mathrm{~m}$. At these parameters application of ozone in a $1 \mathrm{~m}$ thick layer would shorten the drying time by 3 days, 1.5 m layer - by 2 days, 2 m layer - by 1 day, compared to the active ventilation without the use of ozone.

\section{Acknowledgements}

The financial support of the Rural Support Service, Project No 18-00-A01620-000003 "Technology development of grain drying with active ventilation using ozone" is greatly acknowledged. The authors thank Dr.sc.ing. Aivars Cesnieks and Ing. Sandris Cesnieks, the representatives of the "Mazkalnini" Farm, Tervete Region, Tervete District, Latvia, for the support and active cooperation.

\section{References}

[1] Aboltins A., Palabinskis J., Lauva A. Grain active ventilation using ozonized air. Acta Horticulture 2010. 858, pp. 449-456. DOI: 10.17660/ActaHortic.2010.858.69

[2] Granella S.J. et.al. Effect of drying and ozonation process on naturally coantaminated wheat seeds. Journal of cereal science 80, 2018, pp. 205-211. DOI: 10.1016/j.jcs.2018.03.003

[3] Steponavičienė A., Steponavičius D., Raila A., Kemzūraite A. Modelling the ozone penetration in a grain layer. Journal of Environmental Engineering and Landscape Management, 20(4), 2012, pp. 292-300. DOI:10.3846/16486897.2011.645826

[4] Штанько Р.И. Электроозонаторная установка для сушки зерна. Автореферат диссертации на соисание ученой степени кандидата технических наук. 23c., Зерноград, АЧГАА, 2000. Electroozonator installation for drying grain. Abstract of the dissertation of a doctor of technical sciences. 23 pages, Zernograd, AČGAA, 2000. (In Russian)

[5] Голубкович А.В. и др. Эффективность применения озонно-воздушных смесей в процессах сушки зерна. Материалы 26-го всеросийского семинара (г. Москва, Хим. Факультет МГУ им. Ломоносова, 18.дек. 2003г.) - М.: Изд-во Унивеситет и школа, 2003, - с. 67-86. The efficiency of the use of ozone-air mixtures in the drying processes of grain. Materials of the 26th All-Russian Seminar (Moscow, Chem. Faculty of Moscow State University named after Lomonosov, December 18, 2003) - Moscow: Publishing House of the University and the School, 2003, - pp. 67-86. (In Russian).

[6] Raila A., Lugauskas A., Steponavičius D., Railienė M., Steponavičienė A., Zvicevičius E. Application of ozone for reduction of mycological infection in wheat grain. Annals of Agricultural and Environmental Medicine 13 (2), 2006, pp. 287-294.

[7] Троцкая Т.П. Электроактивирование процессов сушки растительных материалов. Автореферат диссертации доктора технических наук. 32c., Москва, ГАУ имени В.П. 
Горячкина, 1998. Electroactivation of drying processes of plant materials. Abstract of the dissertation of a doctor of technical sciences. 32 pages, Moscow, GAU, 1998 (In Russian).

[8] Горский И.В. Обработка семян пшеницы озонированым воздухом. Автореферат диссертации кандидата технических наук. 20с., Москва, ГАУ имени В.П. Горячкина, 2004. Treatment of the wheat seeds with ozonized air. Abstract of the dissertation of a candidate of technical sciences. 20 pages, Moscow, GAU named after V.P. Goryachkin, 2004 (In Russian).

[9] Tiwari B. K., Brennan C. S., Curran T., Gallagher E., Cullen P. J., Donnell C. P. O. Application of ozone in grain processing. Journal of Cereal Science, 51(3), 2010, pp. 248-255. DOI: $10.1016 /$ j.jcs.2010.01.007

[10] Kleperis J., Vorohobovs V., Cēsnieks S., Vilde A., Cēsnieks A. Application of ozone and environmental monitoring methods in grain drying. Proceedings of $4^{\text {th }}$ International Scientific conference "Agricultural Engineering Problems". Jelgava, 2005, pp. 75-78.

[11] Danchenko V.G. (Dnipropetrovsk, UA), Noyes, Ronald T. (Stillwater, OK, US), Potapovych, L.P. (Dnipropetrovsk, UA). Method of aeration disinfecting and drying grain in bulk and pretreating seeds and a transverse blow silo grain dryer therefor. United States Patent Application Publication, Pub.No: US 2009/0191091 A1, Pub. Date: Jul.30.2009.

[12] Rucins A., Viesturs D., Kristins A. Bruveris J. Investigation in intensification of grain drying by active ventilation applying ozone. Proceedings of $19^{\text {th }}$ International Scientific conference "Engineering for Rural Development". Jelgava, 2020, pp. 231-237.

[13] Kleperis J., Kristiņš A., Veibergs J. etc. Application of ozone in grain drying: autonomus sensor system construction and pecularities. Vytautas Magnus university Agriculture academy. Proceedings of the $9^{\text {th }}$ International Scientific Conference Rural Development 2019. DOI: $10.15544 / R D .2019 .029$

[14] Berziņš E. Graudu kondicionēšana. 1-41. lpp, Rīga, Liesma, 1984. Book "Grain Conditioning”. Grain conditioning. Pages 1-41, Riga, Liesma, 1984. Book "Grain Conditioning" (In Latvian).

[15]Ксенз Н.В., Попандопуло К.Х., Сорокин Б.Н., Сидорцов И.Г. Энергосберегающая технология сушки зерна. Механизация и электрификация животноводства, растениеводства, № 2 2010. УДК 631.22.628.8. Energy-saving grain drying technology. Mechanization and electrification of animal husbandry, plant growing, No. 2 2010. UDC 631.22.628.8. (In Russian). 